\title{
Pseudemys nelsoni Carr 1938 - Florida Red-Bellied Turtle
}

\author{
DALE R. JACKSON ${ }^{1}$ \\ ${ }^{1}$ Florida Natural Areas Inventory, Florida State University, \\ 1018 Thomasville Road, Suite 200-C, Tallahassee, Florida 32303 USA [djackson@fnai.org]
}

\begin{abstract}
Summary - The Florida red-bellied turtle,Pseudemys nelsoni (Family Emydidae), is a moderately large turtle (carapace length to $37.5 \mathrm{~cm}$ ) that is relatively abundant in freshwater wetlands throughout peninsular Florida and extreme southeastern Georgia. The species is one of the largest emydids in North America, with females (to $37.5 \mathrm{~cm}$ ) typically growing larger than males (to $30 \mathrm{~cm}$ ). The posthatchling diet consists almost entirely of aquatic plants. Mature females may lay up to five clutches of approximately 10 to 20 eggs each during May through August of each year. Direct human exploitation of the species seems to have been low in the past, but this threat may have increased in the previous decade in conjunction with growing demand by the Asian market for turtle meat. The pet trade market for hatchlings also expanded in the 1990s, with most of the demand met by take of natural nests. Recent regulations governing the harvest of turtles and eggs in Florida, however, should stem nearly all legal take in the future. The greatest potential threats to the species are pollution and drainage or alteration of wetland habitats. Although population status data are unavailable, there is no reason to believe that the species is unduly threatened.

DistRIBUTION. - USA. Distributed in peninsular Florida and southeastern Georgia.

Synonymy. - Deirochelys floridana Hay 1908 (nomen dubium), Trachemys jarmani Hay 1908 (nomen dubium), Pseudemys nelsoni Carr 1938, Pseudemys rubriventris nelsoni,Chrysemys (Pseudemys) nelsoni, Chrysemys rubriventris nelsoni, Pseudemys (Ptychemys) nelsoni (Ward 1984).

SubSPECIES. - None recognized.

STATUS. - IUCN 2009 Red List: Not Listed (= Least Concern, LR/lc) (assessed 1996, needs updating); CITES: Not Listed; US ESA: Not Listed.
\end{abstract}

Taxonomy. - Although Carr (1938) was the first to assign specific status to the disjunct population of red-bellied turtles (sometimes referred to as cooters) in peninsular Florida, others had previously noted their existence. Loennberg
(1894) assigned specimens from north-central peninsular Florida to Pseudemys rubriventris; subsequently, De Sola (1935) referred the Everglades population to Pseudemys alabamensis. Although some later authors (e.g., Mertens

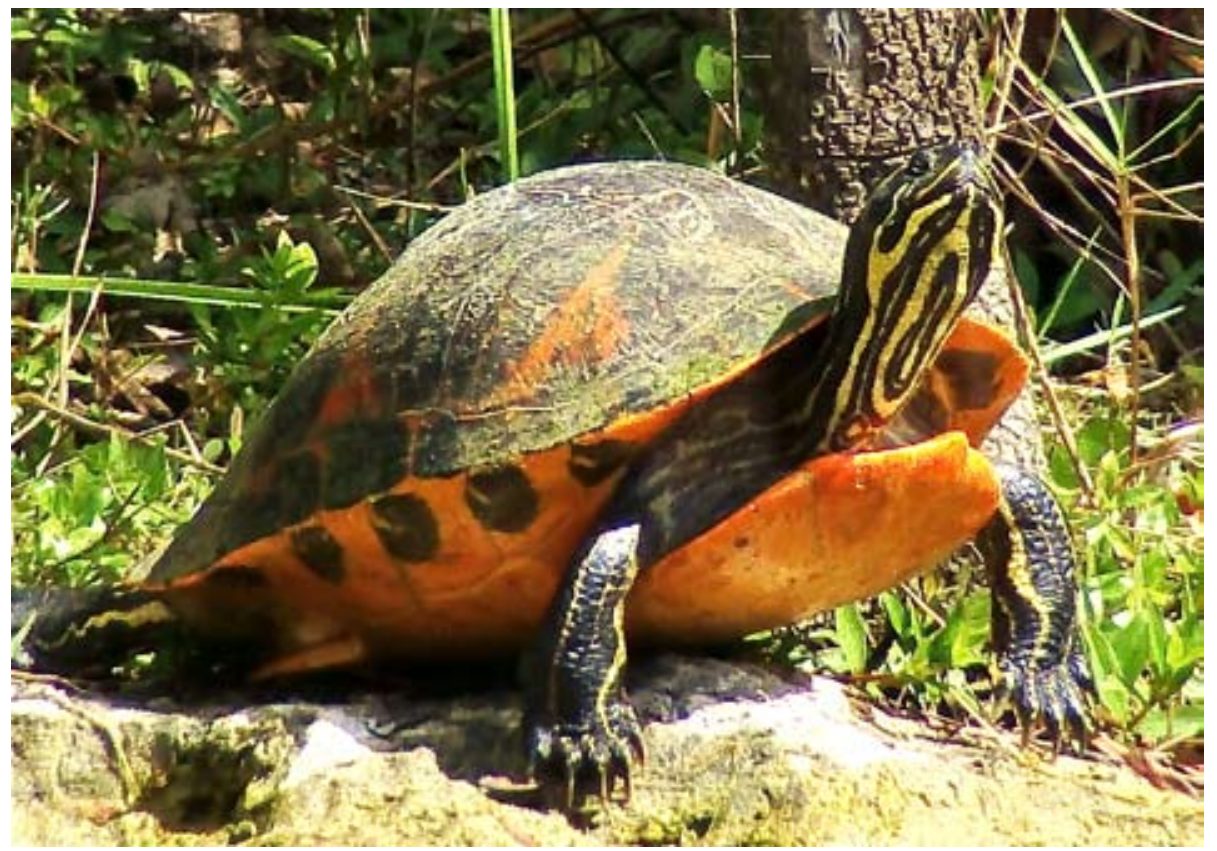

Figure 1. Pseudemys nelsoni, adult female from Big Cypress National Preserve, Collier County, Florida. Photo by Gary Luciano. 


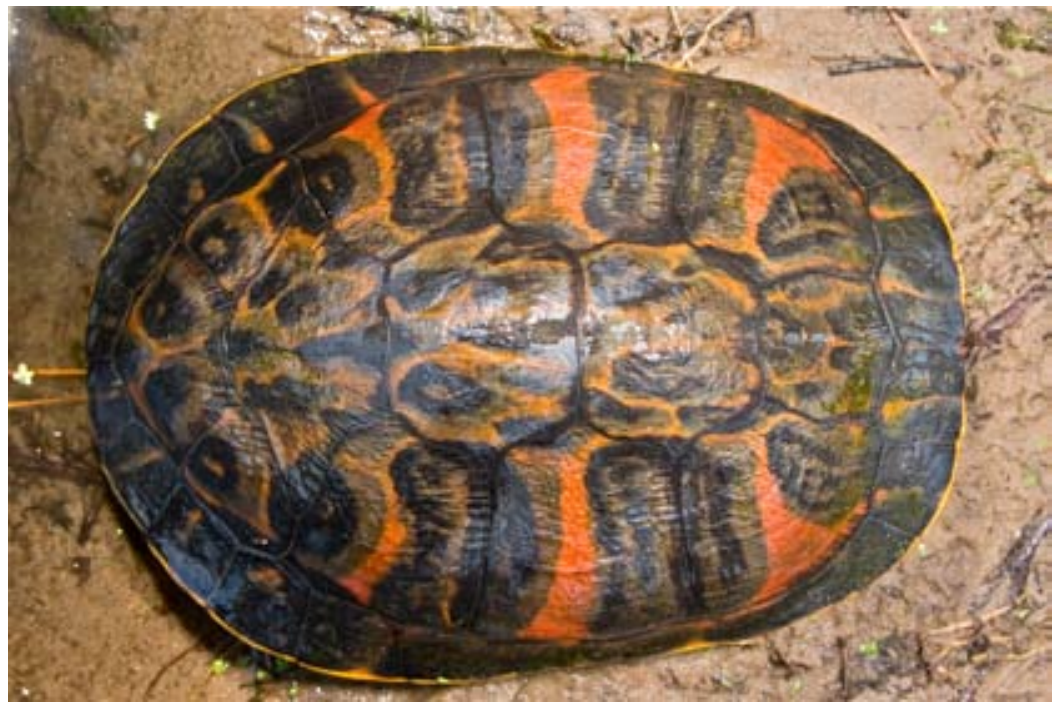

Figure 2. Pseudemys nelsoni, adult male from Marion County, Florida. Photo by Pierson Hill.

1951; Crenshaw 1955) considered nelsoni to be a subspecies of one of those two species, most have followed Carr. The species was included with all other Pseudemys in McDowell's (1964) expanded genus Chrysemys, but most current workers now reject that allocation. No subspecies of P. nelsoni are recognized, although geographic variation has not been examined.

The priority of the name nelsoni may be in question (Jackson 1978). Two species of fossil emydids, Deirochelys floridana Hay 1908 and Trachemys jarmani Hay 1908, both appear to represent P. nelsoni. Although Hay's name floridana is unavailable as a junior secondary homonym of Pseudemys floridana (LeConte 1830), the name jarmani remains potentially available as a senior synonym of nelsoni. However, both names are considered nomina dubia and have never been applied to the extant taxon nelsoni.

Most authorities agree that the three species of redbellied turtles - Pseudemys alabamensis, P.nelsoni, and $P$. rubriventris - form a closely related group, the rubriventris series (Seidel 1994; Stephens and Wiens 2003). Dobie

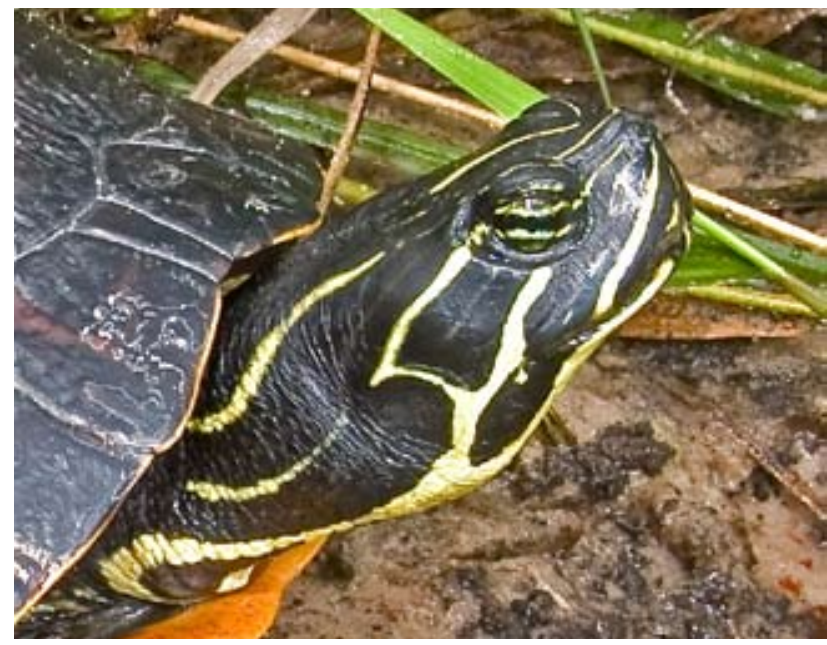

Figure 3. Pseudemys nelsoni, adult male from Lake County, Florida. Photo by Pierson Hill.
(1985) reported a fourth population of red-bellied turtles from the Pascagoula River system of Mississippi that he hypothesized as distinct, but these were shown by Leary et al. (2003) to represent $P$. alabamensis. Whether these disjunct populations would be better treated as subspecies rather than species awaits further systematic studies. Ward (1984) resurrected the subgenus Ptychemys to include the three named species plus $P$. texana, which formerly had been recognized as a subspecies of P. concinna. I do not
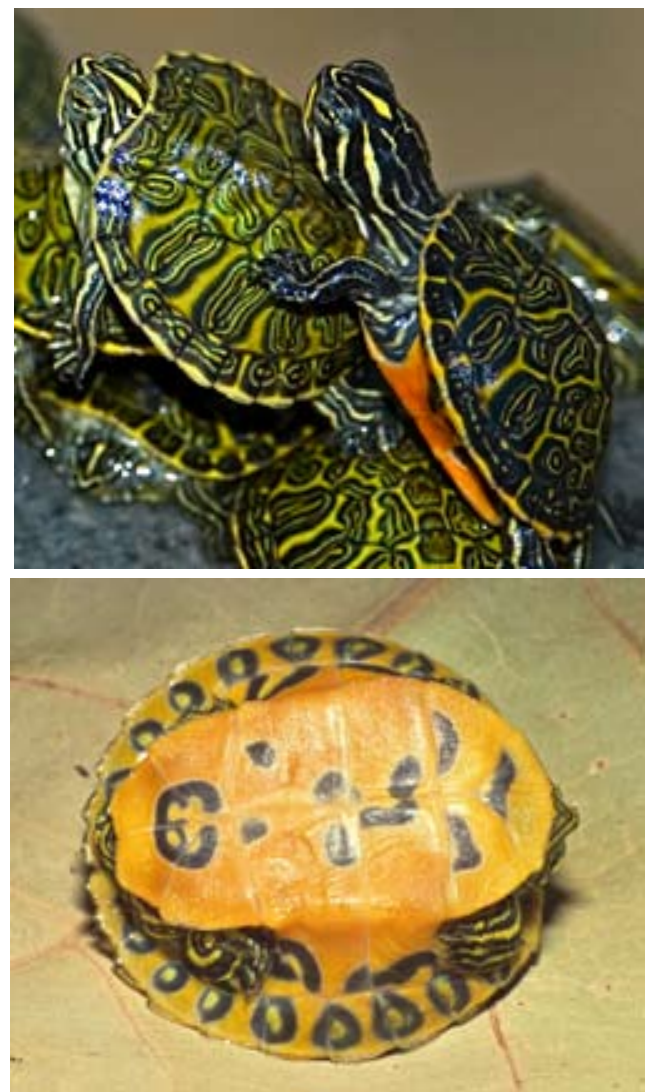

Figure 4. Pseudemys nelsoni, hatchlings from Florida. Photos by Greg Norsworthy (top) and Richard D. Bartlett (bottom). 


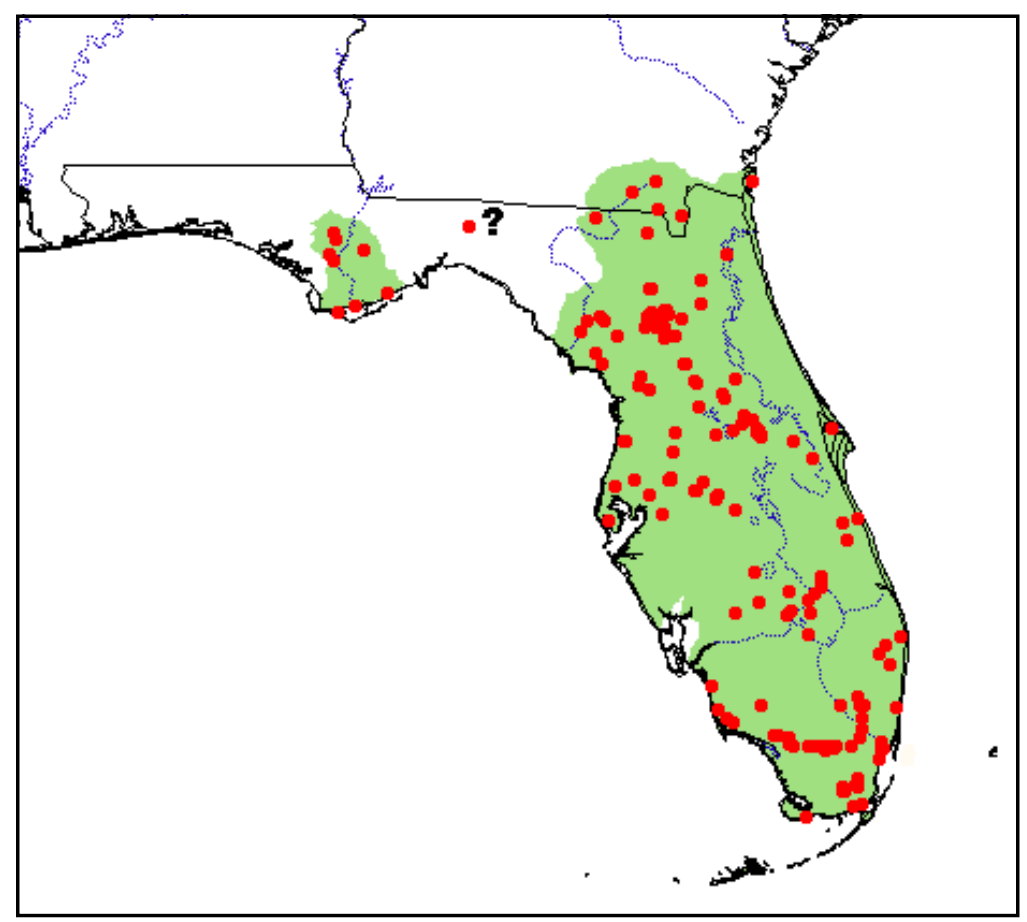

Figure 5. Distribution of Pseudemys nelsoni in Florida and Georgia, southeastern USA. Red points = museum and literature occurrence records based on Iverson (1992) plus more recent and author's data; green shading = projected distribution based on GIS-defined hydrologic unit compartments (HUCs) constructed around verified localities and then adding HUCs that connect known point localities in the same watershed or physiographic region, and similar habitats and elevations as verified HUCs (Buhlmann et al. 2009), and adjusted based on author's data. The questionable locality is Wacissa River (see text).

concur with Ward's removal of texana from P.concinna nor its alignment with the rubriventris series; electrophoretic analysis by Seidel (1994) also supported this viewpoint.

A recent study of emydid turtle genetics by Wiens et al. (2010) demonstrated deep divergences for nuclear DNA among most species, with $P$. nelsoni and $P$. rubriventris closely related and sister to $P$. concinna $+P$. floridana (as "P.peninsularis"; see Thomas and Jansen 2006). However, the results of an analysis of mitochondrial DNA were more equivocal and somewhat discordant, and the red-bellied species $P$. alabamensis was not examined.

Reports of possible hybridization of P. nelsoni with $P$. floridana (Crenshaw 1955, 1965; Carr and Crenshaw 1957) are based on characters of questionable taxonomic utility and remain unsubstantiated. Zweig and Crenshaw (1957) analyzed the serum protein electrophoretic pattern of $P$. nelsoni, and Killebrew (1977) reported the chromosome number $(2 \mathrm{n}=50)$.

Description. - Pseudemys nelsoni is a large emydid turtle, with females and males reaching carapace lengths (CL) of 37.5 and $30.0 \mathrm{~cm}$, respectively. The species has a highly arched carapace, deepest at the midpoint of the shell; greatest carapace width is 1.5 to 1.7 times greatest carapace height. The carapace is ovoid in outline with a smooth to shallowly serrated posterior margin. The surface of the carapace is rugose with distinct sculpturing of vermiculate and narrow parallel ridges. The cervical scute is not deeply incised on the nuchal bone, and its underlap is longer than wide. The carapace is dark, typically black, usually with a single, broad, vertical red bar (sometimes Y-shaped) on each of the first three costal scutes. The plastron is yellow-orange to reddish and generally unmarked, although it may infrequently bear a pattern of dusky blotches. The head and neck usually have only seven yellow stripes on a black background; a prefrontal arrow is frequently formed by the union of the large sagittal stripe and supratemporal stripes on the snout. Usually an orbital and maxillary stripe extend across the temporal region below the supratemporal stripe on each side of the head. The limbs are likewise black and lightly marked with yellow stripes. Sexual dimorphism in adults is confined to the elongate foreclaws and long, thickened tail of males, and the greater maximum body sizes and more highly vaulted shells of females. Melanism may occur in some adults, particularly old males (Barbour and Carr 1940).

The upper jaw has a deep median notch bounded by a cusp on each side. The mandible is strongly serrate along its cutting edge, bears a median cusp, and is flat ventrally; a dorsal symphysial ridge is present. The alveolar surfaces of the jaws are wide, and each bears a well-developed, serrate, longitudinal median ridge. The vomer is incorporated into the upper alveolar surface, and the pterygoids do not reach the exoccipitals. Minimum width of the pterygoids is less than 0.20 skull length. The skull is nearly as broad as long.

The carapace of hatchlings is greenish, circular in outline, and bears a distinct longitudinal keel. The markings are bolder than in adults. The vertical bars on the costals are yellowish green, and the plastron often has black, semicircular, or other symmetric markings bordering the sulci of the scutes. Hatchlings have an average CL of $32.2 \mathrm{~mm}$ (range ca. 29-35) and body mass of $7.5 \mathrm{~g}$ (range ca. 6-9.5). 
Distribution. - Pseudemys nelsoni occurs principally in lentic environments throughout peninsular Florida and extreme southeastern Georgia. Its known range extends southward to Cape Sable and Florida Bay, Florida, and northward to the Okefenokee Swamp and Cumberland Island, Georgia (Duellman and Schwartz 1958; Powers and Smith 1977; Vitt and Dunham 1980; Dunson and Seidel 1986; Shoop and Ruckdeschel 1986; Dunson and Mazzotti 1989; Fahey and Jensen 2008; Atkinson and Butler 2008). Duellman and Schwartz (1958) stated that it does not occur on the Florida Keys, where permanent freshwater bodies are scarce; occasional reports from a sinkhole in the Lower Keys, if accurate, almost certainly represent one or more releases. Recent evidence, reviewed by Iverson and Etchberger (1989) and Jackson (2006), has confirmed the existence of a potentially disjunct population in the Apalachicola region of western Florida, including one offshore island (St. Vincent). A problematic recent record based on a single individual from the Wacissa River (Jackson and Stearns 2005; Jackson 2006) falls within the gap between the Apalachicola region and the main peninsular Florida distribution of the species. Nonetheless, at least some of the earlier reports of the species in western Florida (e.g., Crenshaw 1955; Carr and Crenshaw 1957; Means 1977; Pritchard 1980; R.H. Mount and J.W. Crenshaw, Jr., pers. comm.) were probably based on misidentified $P$. concinna, which in this region tends to resemble P.nelsoni in coloration and development of cusped jaws. One additional specimen reported for western Florida (USNM 95765, Leon County) is based on the incorrect association of a shell of P. nelsoni with the skull of a $P$. floridana.

During the Pleistocene, the range of $P$. nelsoni included not only much of peninsular Florida (D. Jackson 1977; Ernst and Lovich 2009) but extended northward at least to coastal South Carolina (Dobie and Jackson 1979). The fossil South Carolina record helps to fill the hiatus between the presentday range of $P$. nelsoni and that of its northern counterpart, P. rubriventris.

An introduced population of P.nelsoni occurs in the San Marcos River system of Texas and is known to be successfully breeding (Rose et al. 1998). The only other verified extralimital established population was recently documented from man-made ponds in Tortola, British Virgin Islands (Owen et al. 2005; Perry and Gerber 2006). Given the species' increasing presence in the pet trade, other locations can be anticipated.

Habitat and Ecology. - The Florida red-bellied turtle inhabits freshwater marshes, ponds, lakes, and some low-gradient rivers and spring runs. Optimal habitat is characterized by non-flowing water with abundant emergent and submergent vegetation. The species is rare in or absent from oligotrophic, sand-bottomed, sparsely vegetated lakes. Dunson and Seidel (1986) recorded this turtle as present but uncommon in brackish waters (up to $30 \%$ saltwater) in Florida Bay, at the southern tip of the Florida peninsula. Like most emydids, $P$. nelsoni basks extensively, either singly or in groups; mats of vegetation as well as logs and stumps may be used (Pritchard and Greenhood 1968; Kramer 1989; pers. obs.).

Pseudemysnelsoni often coexists with one or more other emydids, including P. floridana, Deirochelys reticularia, the riverine $P$. concinna, and least frequently Trachemys $s$. scripta (with which it is nearly parapatric in the peninsula). In some man-made ponds in south Florida, it also co-exists with the introduced T. s. elegans (Witzell 1999). In optimal habitat, $P$. nelsoni can be numerically dominant (Jackson 2006), although population densities are unavailable. In flowing waters as well as lakes with abundant open water and proportionately less vegetation, it typically occurs at lowerdensities (e.g.,4.6-22.2 turtles per ha: Giovanetto 1992 for Homosassa River, Citrus County, and Rainbow River, Marion County, Florida) and comprises a smaller segment of the emydid fauna (Marchand 1942; Bancroft et al. 1983; Giovanetto 1992; Huestis and Meylan 1994). Nonetheless, in some such situations, it can be abundant (Kramer 1995: 78.6 adults and subadults per ha in Rock Springs Run, Orange County, Florida).

Except for its early juvenile stages, which are poorly studied, P. nelsoni is strictly herbivorous (Carr 1952; Ernst and Barbour 1972; Bancroft et al. 1983; Bjorndal et al. 1997; Jackson 2006; Ernst and Lovich 2009). The diet includes such aquatic plants as Vallisneria, Lemna, Wolffia, Elodea, and Sagittaria. Like most freshwater turtles within its range, this species is subject to predation by American alligators (Alligator mississippiensis) (Delany and Abercrombie 1986) and carnivorous mammals such as otters (Lutra canadensis) and raccoons (Procyon lotor). Wiley and Lohrer (1973) and Ross (1989) additionally recorded small to medium-sized P. nelsoni in the diets of several species of raptorial birds.

Jackson (1988 and unpubl. data) obtained the following reproductive parameters for the species in northern peninsular Florida: male size at maturity, $170-210 \mathrm{~mm}$ plastron length (PL) (corresponding to $187-231 \mathrm{~mm} \mathrm{CL}$ ); female size at maturity, 260-270 mm PL (275-290 mm CL); mean mass of adult females, $4.02 \mathrm{~kg}$; mean adult female size, $290.2 \mathrm{~mm}$ PL (306 mm CL); mean hatchling size, $30.4 \mathrm{~mm}$ PL (31.6-32.2 $\mathrm{mm} \mathrm{CL}$ ); mean hatchling mass, $7.43 \mathrm{~g}$; mean clutch size, 14.3 (range, 7-26); clutches per season, 3-6; mean annual reproductive potential, 64.4 eggs; mean egg mass, $10.23 \mathrm{~g}$; mean egg length, $34.8 \mathrm{~mm}$; mean egg width, $23.2 \mathrm{~mm}$; mean clutch mass, $146.3 \mathrm{~g}$; relative clutch mass, 0.044 . Nesting occurs from May through August, with a June-July peak. Although the species commonly nests in well-drained soils adjacent to freshwater, it also shows a proclivity for nesting in the nest mounds of the American alligator (Goodwin and Marion 1977; Deitz and Jackson 1979; Kushlan and Kushlan 1980; Hunt 1987; Enge et al. 2000).

Development of eggs is rapid, with hatching usually occurring from 45 to 60 days (but sometimes as long as 80 days) after oviposition for eggs incubated at constant temperatures of 25 to $30^{\circ} \mathrm{C}$ (Jackson 1988). Incubation temperature determines sex of offspring (males cooler, females warmer), with a pivotal temperature of approxi- 
mately $28.5^{\circ} \mathrm{C}$ (Ewert et al. 2004). Growth rates mirror the pattern seen in most turtles, with relatively rapid growth in hatchlings and juveniles followed by substantial slowing at maturity. In a central Florida lake, Bancroft et al. (1983) reported a mean annual increase in CL of juveniles of 19.3 $\mathrm{mm} / \mathrm{yr}$, with some individuals exceeding $200 \mathrm{~mm}$ CL in 5 yrs; mean annual growth of adults of both sexes was less than $4 \mathrm{~mm} / \mathrm{yr}$. Although they estimated age at maturity in this population as 3 and 7-8 yrs, respectively, for males and females, these figures are likely underestimates, as they were based on the appearance of secondary sex characters rather than actual evidence of reproductive ability.

Data summarized by Jackson (2006) suggest that populations in optimal habitat are skewed toward adults, whereas a larger juvenile component may survive in somewhat less optimal habitats. This may reflect a greater abundance of alligators, a major turtle predator, in the former situation. In the few populations studied, males seem to outnumber females (Bancroft et al. 1983; Giovanetto 1992; Kramer 1995; Jackson 2006). Home ranges overlap extensively; for at least one riverine population, limited data suggest that they are rather small, averaging only $120 \mathrm{~m}$ linearly (Kramer 1986, 1989, 1995).

Courtship, at least by smaller males, includes a phase in which the male vibrates his elongated foreclaws near the head of the female; as with other Pseudemys, this usually occurs with the male positioned above the female, in contrast to the face-to-face posture seen in Trachemys. Larger males may replace this titillatory phase with biting and dragging of the female. Short fights consisting of gaping and biting may also occur between males, which suggests the existence of dominance hierarchies; territoriality is unlikely (C. Jackson 1977; Kramer 1984, 1986, 1989; Kramer and Fritz 1989).

Parasites of $P$. nelsoni were reviewed by Ernst and Barbour (1972). Further aspects of P. nelsoni ecology were described by Meshaka (1988; commensal algae), Meshaka and Deyrup (1999; consuming algae), and Nebeker and Bury (2000; temperature selection in juveniles).

Population Status. - No data are available. The species occurs in appropriate habitat throughout its range and can achieve relatively high densities (Jackson 2006), but no specific inventories have been conducted to document precise occurrences (presumably many hundred) or trends. There is no reason to suspect major recent changes at a range-wide level, either negative or positive. Habitats utilized by P. nelsoni (larger water bodies, slow rivers) may become degraded but are rarely lost. However, local populations can fluctuate substantially in concert with environmental changes. Severe drought that dries out shallow lake basins, for instance, can cause very high mortality (Dodd 1995; Jackson 2006), yet the timeframe needed for potential recovery with restored conditions is unknown. In at least one instance, the damming of a free-flowing river (the Ocklawaha) to facilitate shipping has led to a local population increase, as the lentic conditions favored by $P$. nelsoni supplanted the former lotic habitat preferred by its congener, $P$. concinna. Efforts to remove the dam and restore the river remain unfulfilled; if successful, the altered balance between the species may likewise reverse.

Threats to Survival. - Although the species is taken occasionally by divers and fishermen for food, this seems to have been relatively uncommon, probably because its typical habitats are largely unavailable to such uses as a result of low clarity, abundance of alligators, and poor accessibility and navigability. Nonetheless, recent concerns have arisen in Florida about mass harvest of freshwater turtles for both the Asian and domestic meat markets, and this may include $P$. nelsoni as well as other Pseudemys spp. (Jackson 2006).

The species' dependence upon wetlands ties its status and survival prospects directly to the condition and maintenance of sufficient wetland habitat. Wetlands throughout Florida are threatened by pollution (both point and non-point source, including acid rain), illegal drainage, destruction of shoreline vegetation in association with residential development, and general shrinkage from lowered water tables as a result of withdrawal for human consumption and excessive use of water from underground aquifers.

Human-induced modifications of wetlands have had varied effects on the species. In southern Florida, creation of semi-artificial wetlands lined with concrete walls, for the purpose of restoring hydrology of the Everglades, has created a situation in which red-bellied and other turtles that enter are trapped and exposed to potentially lethal high temperatures and concentrations of predators. Elsewhere, habitat alterations have led to unnaturally high concentrations of nests and correspondingly high levels of nest predation. Long-term effects of these anthropogenic disturbances on turtle populations are unknown.

In the 1990s, P.nelsoni hatchlings became popular in the pet trade, and the species even became relatively common in the collections of European hobbyists. Enormous numbers of eggs were harvested from natural nests at some sites in southern Florida to supply this demand. Recent rules passed by the Florida Fish and Wildlife Conservation Commission now severely restrict or eliminate legal take of Pseudemys from the wild, including eggs, so that the burden to supply such trade has shifted to captive propagation.

Conservation Measures Taken. - No federal or state agency formally lists $P$. nelsoni as a protected species. However, rules passed in 2009 by the Florida Fish and Wildlife Conservation Commission to curtail take of freshwater turtles from the wild specifically eliminate legal take of all Pseudemys in the state except by special permit. A separate rule passed a decade earlier had already effectively ended commercial collection of eggs. No such rules are in place in adjacent Georgia, which contains only a very small portion of the range of $P$. nelsoni.

The IUCN/SSC Tortoise and Freshwater Turtle Specialist Group (1989) Action Plan included the species in category 4: species for which neither additional investigation nor conservation efforts appeared necessary at the time. The species is not currently listed on the IUCN Red List, and was assessed as Lower Risk/least concern by the Specialist Group in 1996. 
Pseudemys nelsoni occurs in a number of protected areas, including Everglades National Park and Paynes Prairie Preserve State Park in Florida, as well as the Okefenokee National Wildlife Refuge in Georgia, and probably most other protected areas that contain suitable habitat within its range.

Although drainage of wetlands for agriculture and urbanization was a common practice in Florida's recent history, the last two decades have seen a renewed public appreciation of the multiple values of wetlands. State regulations now offer protection to many, but not all, wetland habitats.

Conservation Measures Proposed. - As long as appropriate freshwater wetlands throughout Florida are protected from pollution, drainage, and other unnatural disturbance, the survival prospects of this species appear good. Florida has passed a variety of measures to protect and maintain the state's extensive and varied wetlands, but they omit smaller, isolated wetlands that can be many acres in size. Although many of these tend to be ephemeral wetlands and hence unable to support a permanent population of red-bellied turtles, some are sufficiently large and deep to provide habitat for the species. For years, conservation groups have sought stronger measures from the state's five Water Management Districts, as well as the U.S. Army Corps of Engineers and the Florida Department of Environmental Protection, to protect isolated wetlands; although some progress has been made, measures are still not adequate.

Even though P.nelsoni may no longer be taken legally from the wild in Florida, which represents the vast majority of the species' range, similar measures are needed in Georgia as well. Florida's proactive rule-making may provide impetus to Georgia and other U.S. states (supporting other species) to follow suit.

Field work in western Florida, particularly in the Apalachicola River basin, is needed to delineate the precise distribution of the apparently disjunct population of $P$. nelsoni west of the Suwannee River. Moreover, it will be essential to examine the relationships between $P$. nelsoni and $P$. alabamensis more closely, as well as geographic variation within these species. Additional field work should be performed to determine precise occurrences of P. nelsoni on protected lands throughout the species' range. Certain baseline populations should be established and monitored periodically to serve as indicators of possible declines.

Captive Husbandry. - This species does well in captivity if provided with adequate food, clean fresh water, basking sites, and UV light. Water depth should be at least two to three times the height of the carapace. Natural sunlight and artificial UV lights serve adequately as sources of ultraviolet radiation. Most specimens learn to accept and do well on commercial chow developed for fishes (catfish, trout), although aquatic plants and other vegetation can be used supplementally. Lardie (1973) reported captive hatchlings to be omnivorous. With adequate nutrition, juveniles can grow rapidly, to as large as $300 \mathrm{~g}$ and $125 \mathrm{~mm}$ carapace length in 13 months (McRobert 1995). I have raised one Florida red-bellied turtle for 33 years post-hatching on a diet comprised almost entirely of commercial floating catfish chow (6 $\mathrm{mm}$ pellets), although the turtle did receive (and ate readily) freshly killed freshwater fish and invertebrates during its first two years. Snider and Bowler (1992) reported a wild-caught adult female that lived an additional 26 years in captivity. Mossiman (2006) has documented the successful breeding of two generations in captivity.

Current Research. - The author is engaged in analyses of two studies on the effects of severe drought on P. nelsoni and predation of the species by the American alligator. The Central Florida Freshwater Turtle Study is an ongoing 10year research project that is collecting ecological data on the turtle faunas, which include P.nelsoni, of four central Florida spring runs. Additionally, the Eckerd College Rainbow Run turtle project (supervised by P.A. Meylan), initiated in 1990, continues to sample P.nelsoni, although only as a very minor component of the site's turtle fauna.

\section{LITERATURE CITED}

AtKinson, B.K. AND ButLer, J.M. 2008. Geographic distribution: Pseudemys nelsoni. Herpetological Review 39:481.

Bancroft, G.T., Godley, J.S., Gross, D.T., RoJas, N.N., SutPhen, D.A., AND MCDIARMID, R.W. 1983. Large-scale operations management test of use of the white amur for control of problem aquatic plants; the herpetofauna of Lake Conway, Florida: species accounts. Miscellaneous Paper A-83-5, U.S. Army Engineer Waterways Experiment Station, CE, Vicksburg, Mississippi.

Barbour, T. AND CARR, A.F., JR. 1940. Antillean terrapins. Memoirs of the Museum of Comparative Zoology 54(5):381-415.

BJorndal, K.A., Bolten, A.B., Lagueux, C.J., And Jackson, D.R. 1997. Dietary overlap in three sympatric congeneric freshwater turtles (Pseudemys) in Florida. Chelonian Conservation and Biology 2:430-433.

Buhlmann, K.A., Akre, T.S., Iverson, J.B., Karapatakis, D., Mittermeier, R.A., Georges, A., Rhodin,A.G.J., van DiJK, P.P., AND GibBons, J.W. 2009. A global analysis of tortoise and freshwater turtle distributions with identification of priority conservation areas. Chelonian Conservation and Biology 8(2):116-149.

CARr, A.F., JR. 1938. Pseudemys nelsoni, a new turtle from Florida. Occasional Papers of the Boston Society of Natural History 8:305-310.

CARr, A.F. 1952. Handbook of Turtles. The Turtles of the United States, Canada, and Baja California. Ithaca, NY: Cornell University Press, $542 \mathrm{pp}$.

CARr, A.F., JR. ANd Crenshaw, J.W., JR. 1957. A taxonomic reappraisal of the turtle Pseudemys alabamensis Baur. Bulletin of the Florida State Museum, Biological Science 2:25-42.

Crenshaw, J.W., JR. 1955. The ecological geography of the Pseudemys floridana complex in the southeastern United States. Ph.D. Thesis, University of Florida, Gainesville.

CRenshaw, J.W., JR. 1965. Serum protein variation in an interspecies hybrid swarm of turtles of the genus Pseudemys. Evolution 19:1-15.

DeITZ,D.C. AND JACKSON, D.R. 1979. Use of American alligator nests by nesting turtles. Journal of Herpetology 13(4):510-512.

Delany, M.F. And Abercrombie, C.L. 1986. American alligator habits in northcentral Florida. Journal of Wildlife Management 50:348-353.

DESola,C.R.1935. Herpetological notes from southeastern Florida. Copeia 1935(1):44-45.

DobIE, J.L. 1985. Distribution and status of the Alabama red-bellied 
turtle, Pseudemys alabamensis Baur. Final Report to U.S. Fish and Wildlife Service, Contract No. 14-16-0009-1546, 31 pp.

Dobie, J.L. AND JACKSON, D.R. 1979. First fossil record for the diamondback terrapin, Malaclemys terrapin (Emydidae), and comments on the fossil record of Chrysemys nelsoni (Emydidae). Herpetologica 35(2):139-145.

DodD, C.K., JR. 1995. Disarticulation of turtle shells in north-central Florida: how long does a shell remain in the woods? American Midland Naturalist 134(2):378-387.

Duellman, W.E. and Schwartz, A. 1958. Amphibians and reptiles of southern Florida. Bulletin of the Florida State Museum, Biological Science 3:181-324.

Dunson, W.A. And MazzotTi, F.J. 1989. Salinity as a limiting factor in the distribution of reptiles in Florida Bay: a theory for the estuarine origin of marine snakes and turtles. Bulletin of Marine Science 44(1):229-244.

Dunson, W.A.AND SeIDEL,M.E.1986.Salinity tolerance of estuarine and insular emydid turtles (Pseudemys nelsoni and Trachemys decussata). Journal of Herpetology 20(2):237-245.

Enge, K.M., Percival, H.F., Rice, K.G., Jennings, M.L., Masson, G.R., AND WoOdWARD, A.R. 2000. Summer nesting of turtles in alligator nests in Florida. Journal of Herpetology 34:497-503.

ERnst, C.H. AND BARbOUR, R.W. 1972. Turtles of the United States. Lexington: University Press of Kentucky, 347 pp.

ERnst, C.H. AND Lovich, J.E. 2009. Turtles of the United States and Canada. Second Edition. Smithsonian Institution Press, Washington, D.C.

Ewert, M.A., Etchberger, C.R., And Nelson, C.E. 2004. Turtle sex-determining modes and TSD patterns, and some TSD pattern correlates. In: Valenzuela, N. and Lance, V. (Eds.). Temperaturedependent sex determination in vertebrates. Washington, D.C., Smithsonian Books, pp. 21-33.

FAHEY, K.M. AND JenSEN, J.B. 2008. Florida red-bellied cooter. In: Jensen, J.B., Camp, C.D., Gibbons, W., and Elliott, M.J. (Eds.). Amphibians and Reptiles of Georgia. University of Georgia Press, Athens, Georgia.

GiovanetTo,L.A. 1992. Population ecology and relative abundance of sympatric freshwater turtles in the headwaters of two spring-fed rivers in western peninsular Florida. Ph.D. Dissertation, Florida Institute of Technology, Melbourne.

GoODwIN, T.M. AND MARION, W.R. 1977. Occurrence of Florida red-bellied turtle eggs in north-central Florida alligator nests. Florida Scientist 40:237-238.

HaY, O.P. 1908. The Fossil Turtles of North America. Carnegie Institute. Washington Publication 75:1-568.

Huestis, D.L. And MeYlan, P.A. 2004. The turtles of Rainbow Run (Marion County, Florida): observations on the genus Pseudemys. Southeastern Naturalist 3:595-612.

HunT, R.H. 1987. Nest excavation and neonate transport in wild Alligator mississippiensis. Journal of Herpetology 21:348-350.

IUCN/SSC Tortoise and Freshwater Turtle Specialist Group. 1989. Tortoises and Freshwater Turtles. An Action Plan for their Conservation. Gland, Switzerland: IUCN, 48 pp.

IvERSON, J.B. 1992. A Revised Checklist with Distribution Maps of the Turtles of the World. Richmond, Indiana: Privately printed, $363 \mathrm{pp}$.

IVERSON, J.B. AND ETCHBERGER, C.R. 1989. The distributions of the turtles of Florida. Florida Scientist 52(2):119-144.

JACKSON, C.G., JR. 1977. Courtship observations on Chrysemys nelsoni (Reptilia, Testudines, Testudinidae). Journal of Herpetology 11(2):221-222.

JACKSON,D.R. 1977. The fossil freshwater emydid turtles of Florida. Ph.D. Thesis, University of Florida, Gainesville, Florida.
JACKSON, D.R. 1978. Chrysemys nelsoni. Catalogue of American Amphibians and Reptiles 210:1-2.

JACKSON,D.R. 1988. Reproductive strategies of sympatric freshwater emydid turtles in northern peninsular Florida. Bulletin of the Florida State Museum, Biological Science 33:113-158.

JACKSON,D.R.2006.Pseudemys nelsoni-Florida red-bellied turtle. In: Meylan, P.A. (Ed.). Biology and Conservation of Florida Turtles. Chelonian Research Monographs No. 3, pp. 313-324.

JACKSON, D.R. AND STEARNS, B.C. 2005. Geographic distribution: Pseudemys nelsoni. Herpetological Review 36(4):466.

Killebrew, F.C. 1977. Mitotic chromosomes of turtles: IV. The Emydidae. Texas Journal of Science 29:245-254.

Kramer,M.1984.Life history notes. Pseudemys nelsoni. Behavior. Herpetological Review 15(4):113-114.

Kramer, M. 1986. Field studies on a freshwater Florida turtle, Pseudemysnelsoni.In: Drickamer,L.C.(Ed.). Behavioral Ecology and Population Biology. Toulouse: Privat, pp. 29-34.

Kramer, M. 1989. The behavior and natural history of the Florida red-bellied turtle,Pseudemys nelsoni: an ethnological study.Ph.D. Thesis, University of Tennessee, Knoxville, Tennessee.

KRAMER,M. 1995. Homerange of the Florida red-bellied turtle (Pseudemys nelsoni) in a Florida spring run. Copeia 1995:883-890.

Kramer, M. and Fritz, U. 1989. Courtship of the turtle, Pseudemys nelsoni. Journal of Herpetology 23(1):84-86.

KuSHlan,J.A. AND Kushlan, M.S. 1980. Everglades alligator nests: nesting sites for marsh reptiles. Copeia 1980(4):930-932.

LARDIE, R.L. 1973. Notes on courtship, eggs, and young of the Florida red-bellied turtle, Chrysemys nelsoni.HISS News-Journal 1(6):183-184.

Leary, C.J., Dobie, J.L., Mann, T.M., AND Floyd, P.S. 2003. Morphological variation in the endangered Alabamared-bellied cooter (Pseudemys alabamensis) and taxonomic status of a population in Mississippi. Chelonian Conservation and Biology 4:635-641.

LeConte, J. 1830. Description of the species of North American tortoises. Annals of the Lyceum of Natural History, New York 3:91-131.

LoENNBERG, E. 1894. Notes on reptiles and batrachians collected in Florida in 1892 and 1893. Proceedings of the U.S. National Museum 17:317-339.

MARChAND, L.J. 1942. A contribution to a knowledge of the natural history of certain freshwater turtles. M.S. Thesis, University of Florida, Gainesville.

McDowell, S.B. 1964. Partition of the genus Clemmys and related problems in the taxonomy of the aquatic Testudinidae. Proceedings of the Zoological Society of London 143:239-279.

MCRobert, S.P. 1995. Juvenile growth rates in turtles. Reptile and Amphibian Magazine 36:39-45.

Means, D.B. 1977. Aspects of the significance to terrestrial vertebrates of the Apalachicola River drainage basin, Florida. Florida Marine Research Publication 26:37-67.

Mertens, R. 1951. Zwischen Atlantik und Pazifik. Zoologische Reiseskizzen aus Nordamerika. Stuttgart: D. Gundert Verlag, $160 \mathrm{pp}$.

MeshaKa, W.E., JR. 1988. Life history notes. Pseudemys nelsoni (Florida red-bellied slider). Mutualism. Herpetological Review 19(4):88.

MeshaKa, W.E., JR. AND Deyrup, M. 1999. Pseudemys floridana peninsularis and P. nelsoni. Mutualism. Herpetological Review 30(2):95.

Mossiman,D.2006. Notes on the reproductionin captivity of a second generation of Pseudemys nelsoni. In: Artner, H., Farkas, B., and Loehr V. (Eds.). Turtles. Proceedings: International Turtle and Tortoise Symposium, Vienna 2002. Edition Chimaira, Frankfurt 
am Main, pp. 250-256.

NeBEKER, A.V.and BuRY, R.B.2000.Temperature selection by hatchling and yearling Florida red-bellied turtles (Pseudemys nelsoni) in thermal gradients. Journal of Herpetology 34(3):465-469.

Owen, J., Perry, G., Lazell, J., and Petrovic, C. 2005. Geographic distribution: Pseudemys nelsoni. Herpetological Review 36:466.

Perry, G. AND Gerber, G.P. 2006. Conservation of amphibians and reptiles in the British Virgin Islands: status and patterns. Applied Herpetology 3:237-256.

Powers, A. AND Smith, C.R. 1977. Geographic distribution: Chrysemys nelsoni. Herpetological Review 8(3):84.

PRITCHARD, P.C.H. 1980. Record size turtles from Florida and South Amerika. Chelonologica 1(3):113-123.

Pritchard, P.C.H. and Greenhood, W.F. 1968. The sun and the turtle. International Turtle and Tortoise Society Journal 2(1):20-25, 34 .

Rose, F.L., Manning, R.W., Simpson, T.R., And Jenkins, S. 1998. A sustaining population of the Florida red-bellied turtle, Pseudemys nelsoni (Reptilia: Emydidae), in Spring Lake, Hays County, Texas. Texas Journal of Science 50:89-92.

Ross, D.A. 1989. Amphibians and reptiles in the diets of North American raptors. Wisconsin Endangered Resources Report No. 59, 33 pp.

SEIDEL,M.E. 1994.Morphometric analysis and taxonomy of cooter and red-bellied turtles in the North American genus Pseudemys (Emydidae). Chelonian Conservation and Biology 1(2):117-130.

Shoop, C.R. And Ruckdeschel, C. 1986. New herpetological records for Cumberland Island, Georgia. Herpetological Review 17(2):51.

SNIDER, A.T. AND Bowler, J. K. 1992. Longevity of reptiles and amphibians in North American collections, second edition. Society for the Study of Amphibians and Reptiles Herpetological Circular 21:1-40.
STEPHENS, P.R. AND WiENS, J.J. 2003. Ecological diversification and phylogeny of emydid turtles. Journal of the Linnaean Society 79:577-610.

Thomas, R.B. AND J ANSEN, K.P. 2006. Pseudemys floridana-Florida cooter.In: Meylan,P.A.(Ed.). Biology and Conservation of Florida Turtles. Chelonian Research Monographs No. 3, pp. 338-347.

VitT, L.J. And Dunham, A.E. 1980. Geographic distribution: Chrysemys nelsoni. Herpetological Review 11(3):80.

WARD, J.P. 1984. Relationships of chrysemyd turtles of North America (Testudines: Emydinae). Special Publications of the Museum of Texas Tech University 21:1-50.

Wiens, J.J., KuCZYNSKi, C.A., AND StePHENS, P.R. 2010. Discordant mitochondrial and nuclear gene phylogenies in emydid turtles: implications for speciation and conservation. Biological Journal of the Linnean Society 99:445-461.

WILEY, J.W AND LOHRER, F.E. 1973. Additional records of non-fish prey taken by ospreys. Wilson Bulletin 85(4):468-470.

WITZELL,W.N.1999.Aquatic turtles(Testudines: Emydidae)in anurban south Florida man-made pond. Florida Scientist 62:172-174.

Zweig, G. AND Crenshaw, J.W. 1957. Differentiation of species by paper electrophoresis of serum proteins of Pseudemys turtles. Science 126:1065-1067.

\section{Citation Format for this Account:}

JACKsON, D.R. 2010. Pseudemys nelsoni Carr 1938 - Florida redbellied turtle. In: Rhodin, A.G.J., Pritchard, P.C.H., van Dijk, P.P., Saumure, R.A., Buhlmann, K.A., Iverson, J.B., and Mittermeier, R.A. (Eds.). Conservation Biology of Freshwater Turtles and Tortoises: A Compilation Project of the IUCN/SSC Tortoise and Freshwater Turtle Specialist Group. Chelonian Research Monographs No. 5, pp. 041.1-041.8, doi:10.3854/crm.5.041.nelsoni. v1.2010, http://www.iucn-tftsg.org/cbftt/. 